\title{
O dijaloškome dodiru židovstva i kršćanstva u farizejskoj i Isusovoj etici
}

\author{
Ljudevit Fran Ježić*
}

\begin{abstract}
Sažetak
Pomoću hebraistike, grecistike i poredbeno-povijesne metode u religiologiji, rad istražuje etiku ranih (judeo)kršćana i farizeja kao usko povezanih židovskih sljedaba u 1. stoljeću. Nakon što ističe razlike između farizejskih škola Hillela $i$ Sammâya te razmatra je li i Isus bio ḥâkām, rad tumači razgovor o najvećoj zapovijedi u Mk 12 kao susret u dijalogu između farizeja Hillēlove škole i Isusa. Rad nastoji doprinesti međureligijskomu dijalogu i razumijevanju bitne povezanosti religije s etikom.
\end{abstract}

Ključne riječi: židovsko-kršćanski dijalog; Hilel Stariji; Hilelova škola; farizejska etika; Isusova etika; Zlatno pravilo; najveća zapovijed; poniznost; milosrde

\section{Uvod}

Židovstvo i kršćanstvo mogu pomoću poredbene religiologije više znati o svojim izvorima i o vrijednostima u vlastitim tradicijama nego što bi znali iz svojih tradicija uzetih zasebno. Talmud i ostali rabinski spisi pomažu razumjeti Novi zavjet, a Septuaginta, Novi zavjet i ranokršćanski spisi pomažu razumjeti formativno doba za rabinsko židovstvo kao malo koji drugi dokument, izuzev djela heleniziranih Židova Josipa Flavija i Philōna Alexandrijskoga, koje su također sačuvali kršćani. Židovski i kršćanski apokrifi, kao i svitci sa Crnoga mora pomažu da se razumije bogata raznolikost i silnice religioznoga života u stoljećima oko prijelaza stare u novu eru, a pomažu i da se razumije Kur'an (Qur'ān), na koji su utjecali nekada i više nego kanonske predaje židovstva i kršćanstva, stoga apokrifi potpomažu i dijalog u široj »abrahamskoj ekumeni« (Kuschel, 2000, 15-17). No za međureligijski dijalog na osnovi poredbene religiologije potrebno je i da se neki stari sukobi smirenije i podrobnije razmotre ili kao odnosi nanovo vrjednuju, prije svega sporni odnos između farizeja, glavnih preteča rabinskoga

* Doc. dr. sc. Ljudevit Fran Ježić, Filozofski fakultet Sveučilišta u Zagrebu. Adresa: Ivana Lučića 3, 10000 Zagreb, Hrvatska. ORCID iD: https://orcid.org/0000-0003-2431-8366.

E-adresa:ljfjezic@gmail.com 
judaizma među židovskim sljedbama, i Isusa, začetnika židovske sljedbe koja se je ubrzo raširila izvan židovskih zajednica i na koncu odvojila kao zasebna kršćanska religija.

U 1. stoljeću ni farizeji ni kršćani nisu bili monolitne skupine. Novi zavjet svjedoči o podjelama između "judeokršćana”, koji su kao farizeji (ili izvorni pripadnici drugih židovskih sljedaba) i dalje obdržavali Mojsijev vjerozakon, i "etnokršćana”, koji ga kao vjernici pogani nikada nisu usvojili (Dj 15,5). Rabinski izvori pak svjedoče o razlikama i neslaganjima oko tumačenja vjerozakona, ali i morala i soteriologije između Hiillēlove i Šammâyeve škole (Bêt Hillēl i Bêt Šammây).

\section{Razlike između Hillēlove i Šammâyeve škole}

Budući da su podatci o Ḥillēlovu životu i djelovanju, o njegovim izrekama i vjerskopravnim pravorijecima raštrkani diljem rabinskih izvora, rijetki su svje-

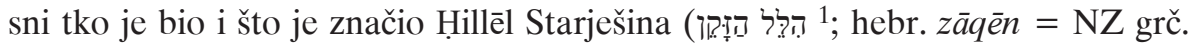
$\pi \rho \varepsilon \sigma \beta v i \tau \varepsilon \rho \varsigma \varsigma)$. Za njihovo sabiranje i rekonstruktivno sagledavanje i razumijevanje veoma je korisna — i za kršćane nemalo poučna — knjiga Yitzhaka Buxbauma The Life and Teachings of Hillel iz 1994. godine (ovdje Buxbaum, 2004).

Hillēl je bio babilonski Židov koji je oko 60. pr. Khr. kao mladić došao u Jeruzalem nastaviti svoj studij vjerozakona (Tore) pod dvojicom židovskih učenjaka koje je Hiillēl s pogledom unazad ocijenio »najvećom dvojicom [učitelja vjerozakona] u naraštaju « (Buxbaum, 2004, 16; BT Pesahim 66a6). ${ }^{2}$ Taj par, naime Šmma yâ i ${ }^{\text {} A b ̣ t a l y o ̂ n, ~}{ }^{3}$ i sami konvertirani Assyrci, bili su pretposljednji u nizu parova (hebr. zû̄got t, "suupregnutih") učenjaka na čelu farizejske sljedbe, za kojima su kao posljednji "par” uslijedili samo Hiillēl i Šammây, čije su različitosti i dovele do čuvenoga i dugotrajnoga spora unutar sljedbe. Kakvi su bili ti učitelji i kakav je bio mladi Ḥillēl, najbolje svjedoči anegdota sačuvana u Talmudu (BT Yoma 35b) iz koje saznajemo da je mladi Ḥillēl kao siromašan najamni radnik jednom u

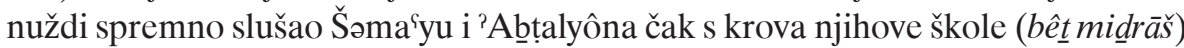

1 Ime הִִּ un u engleskoj transkripciji piše se Hillel, u hrvatskoj transkripciji Hilel (Da-Don, 2009, 494). Auktor ovoga članka hebrejske riječi i imena (izuzev veoma poznata i uhodana: Mojsije, Aron, Ezra, Isus, Pavao) ne piše ni u jednoj transkripciji (prijepisu) nego u jezično obavijesnoj latiničkoj transliteraciji (prijeslovu) kakvu je poučavao njegov profesor hebrejskoga dr. fra Božo Lujić (Lujić, 1996, 1-2) slijedeći mnogo rabljeni sveučilišni udžbenik američkoga semitista Thomasa Lambdina (Lambdin, 1971, XXII-XXV). Ta se transliteracija podudara s međunarodnim standardom ISO 259 kada je riječ o transliteraciji hebrejskih suglasa, a za samoglase daje rješenja koja su bliža transliteraciji grčkoga alfabeta i u cjelini prirodnija i praktičnija. U toj transliteraciji spomenuto se ime piše Hillēl.

2 Hrvatski prijevodi mjesta iz Biblije označeni uvriježenom biblijskom kraticom dani su prema izdanju Biblije navedenome u Literaturi osim ako uz kraticu nije istaknuto da se radi o prijevodu auktora članka na osnovi hebrejskoga ili grčkoga izvornika navedenoga u Literaturi. Auktor također daje vlastitu raščlambu i jezično tumačenje pojedinih biblijskih mjesta, pa su takva mjesta označena drugom vrstom navodnika. Ostale je citate s hebrejskoga i grčkoga auktor članka sam preveo za potrebe ovoga rada.

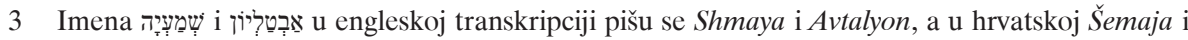
Avtalion (Da-Don, 2009, 494). 
i pod snijegom, a da su njegovi učitelji, kada su ga sutradan našli onesviještena na krovu pod snijegom, rado prekršili propise šabata da bi čovjeku spasili život, očistili ga i ugrijali (Buxbaum, 2004,17). U takvu načelu, premda dakako mnogo šire primijenjenome, slijedit će ih i Isus suprotstavljajući se farizejima šammâyevcima u zabrani liječenja bolesnikâ ili čak trganja i jedenja klasja na šabat (Mk 2,23-3,6): »Šabat je stvoren radi čovjeka, a ne čovjek radi šabata. A tako je Sin Čovječji gospodar i šabata!« (Mk 2,27-28, vlastiti prijevod Lj. F. J.). Iznimke za liječenje bolesnika i jedenje na šabat (i Jom Kipur) na koncu su, slijedeći takvu tradiciju Ḥillēlove škole, usvojili i rabini u Mišni (Mishnah Yoma 8).

Hiillēl je po rabinskoj predaji bio nāsís (glavni autoritet među farizejima, možda i "predsjednik" farizejâ u Sanhedrinu) vjerojatno oko 30. pr. Khr. — 10. po. Khr. (Buxbaum, 2004, 45), a u otprilike je isto doba Šammây Starješina (שِ (ה) $)^{4}$ navodno nosio titulu 'āa b be $\underline{\underline{t}} \underline{\mathrm{T}}$ dîn ("predsjednik" židovskoga vrhovnoga suda), da bi ubrzo po smrti Hiillēla i njegova sina sam bio nāsî̀ do oko 30. godine, dakle i u doba Isusova djelovanja. Sukob između Hillēla i Šammâya izbijao je ne samo zbog razlike u njihovim naravima i podrijetlu, nego i zbog različitih načela koja su usadili učenicima. Sukob se je zato posebno razbuktao i razgranao među njihovim učenicima, pa Talmud govori da je »vjerozakon [Tôrâ] postao kao dva vjerozakona [štê Tôrôt] « (BT Sanhedrin $88 \mathrm{~b} 7$ i dalje). Ovo su glavni razlozi:

1. Hiillēl je posebnu pobožnost farizeja gradio kao ḥâsî́, tj. na milosrdnoj ljubavi prema bližnjemu (hebr. ḥese $\underline{\text { d) }}$ ), a Shammai kao pārûš, tj. u svetosti kao "odvojenosti" od svih koji su smatrani grješnima i nepobožnima (Buxbaum, 2000,

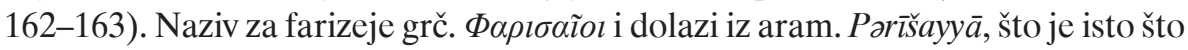
u hebr. Prûšsim (množ. od pārûš) i znači “odvojeni; sveti”. Ti su "sveti” uporište za svoj stav nalazili u Lev 19,2 i 20,26: »Sveti budite! Jer sam svet ja, YHWH, Bog vaš! « (Lev 19,2, vlastiti prijevod Lj. F. J.); »Budite mi dakle sveti [qadôŝ̌im], jer sam ja, YHWH, svet [qādốš]; ja sam vas odvojio od tih naroda ['ammîm] da

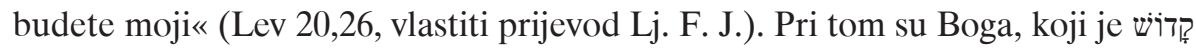

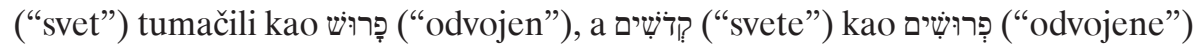

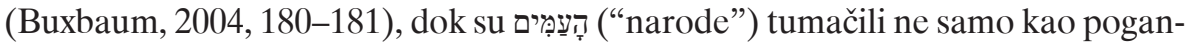

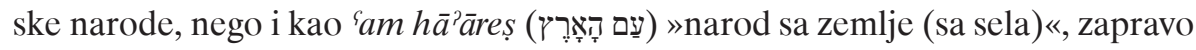
»narodna mnoštva, puk ili svjetina koja ne pozna vjerozakon « (BT Berakhot 47b;

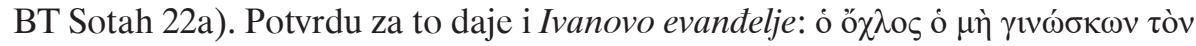
vó "farizejski pisari" također daje Mk 2,16.

2. Hillēl je bio zagovaratelj i učitelj siromašnih i nižih slojeva društva, a Šammây bogatih i uglednih po rodu (Buxbaum, 2004, 50-54; BT Avot D'Rabbi Natan 2,9). ${ }^{5}$ Hillēl i njegova škola borili su se da naobrazba bude dostupna svim

4 Ime שַׁמאי u engleskoj transkripciji piše se Shammai, u hrvatskoj transkripciji Šamaj (Da-Don, 2009, 494).

5 Buxbaum na navedenom mjestu tumači kako Hillēlova uredba prozbul pokazuje njegovu društvenu osjetljivost: Mishnah, Gittin 4,3; Mishnah, Sheviit 10; BT Gittin 32a 15-16. U nas to tako tumači Da-Don $(2009,572)$. 
zainteresiranima jer su ju visoko vrjednovali (Mishnah, Pirkei Avot 2,5; BT Avot D’Rabbi Natan 3,6 i 4,1).

3. Hiillēl je u pravilu bio sklon blažemu tumačenju ili možda čak ublažavanju vjerozakona, a Šammây u pravilu sklon krajnje revnu i legalistički čvrstu i strogu pridržavanju vjerozakonskih obveza (od 316 sporova dviju škola spomenutih u Talmudu u samo 55 njih su šammâyevci na blažoj strani, kažu Jastrow i Mendelsohn, 1902, 115). Anegdotalnim su postali Šammâyeva briga da micvu boravka pod sjenicom (sukkâ) na Sukot ispuni čak i novorođenče njegove snahe (iako su mališani slobodni od micve) te Šammâyevo odbijanje da na Jom Kipur hrani vlastitu djecu zbog micve o zabrani pranja ruku na taj blagdan (Mishnah, Sukkah 2,8; BT Chullin 107b11).

4. Hillēl je i po ćudi bio blag, ponizan i strpljiv te otvoren za pogane i grješnike, pa je zato vješto obraćao pogane na židovstvo, a Šammây je bio nestrpljivije, osornije i ratobornije naravi i manje otvoren za pogane prozelite, pa je zato, kako svjedoči nekoliko anegdota, neke od pogana s posebnim zahtjevima odbio kao nedostojne obraćenja, nakon čega je Ḥillēl svakoga od njih preobratio strpljivim i lukavim osobnim pristupom (BT Shabbat 31a). Po rabinskoj predaji, »glas s neba« (bat $q \hat{o} l)$ presudio je spor u halahi između Šammâyeve i Ḥillellove škole u korist potonje jer su članovi te škole bili »dobrostivi i ponizni« i jer su poučavali i pravorijeke Šammâyeve škole te im čak davali i prednost pred svojima (BT Eruvin 13b10-11).

5. Hillēl je bio krajnje miroljubiv i osuđivao svako nasilno djelovanje (Mishnah, Pirkei Avot, 2,6; BT Sukkah 53a4), pa su on i njegova škola, kao već prije Šəma'yâ i ’Abțalyôn (Josip Flavij, 1892, 333; Antiquitates Judaicae 15.1-4), poticali miran suživot s vlašću Hērōda Velikoga i njegovih nasljednika te Rimljana, a Šammâyeva je škola bila neprijateljski nastrojena prema stranoj rimskoj vlasti, pa i prema poganima i onim Židovima koji su surađivali s rimskom vlašću ili uopće kupovali hranu i piće od poganskih susjeda (Jastrow i Mendelsohn, 1902, 116), u čem su im bili slični ratoborni zeloti, koji su od njih vjerojatno i potekli, ${ }^{6}$ što je židovski povjesničar Heinrich Grätz već 1856 . mnogim razlozima učinio vjerojat$\operatorname{nim}$ (Grätz, $\left.{ }^{2} 1863,485-486\right){ }^{7}$

Unatoč razlikama između dviju škola i ponekim javnim sukobima, njihovi pripadnici nisu zapravo bili krvni neprijatelji. Zabilježeno je da su primjerice pripadnici jedne škole uzimali žene iz porodica druge škole (Mishnah, Yevamot 1,4).

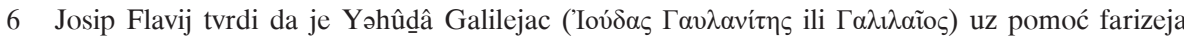

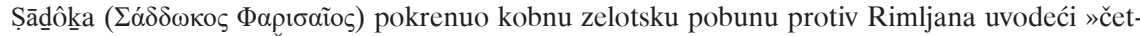
vrtu filozofiju « među Židovima »koja se u svem ostalom slaže s mišljenjem farizejâ, samo što je

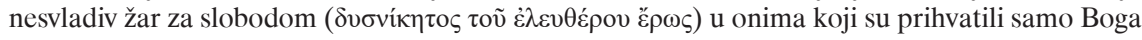
za vladara i gospodara« (Josip Flavij, 1890, 140; Antiquitates Judaicae 18.1-10).

7 Već je iduće godine Grätzov izvod prihvatio drugi veliki židovski povjesničar 19. stoljeća Isaak Markus Jost (1857, 269). Sjajno je Grätz ukazao u navedenoj »Napomeni 23« trećega sveska svoje Povijesti Židova, između ostaloga, na neobičnu okolnost da su šammâyevci, iako obdržavatelji mnogo strožega mirovanja na šabat od hillēlovaca, dopuštali Židovima da se na šabat ne samo brane od pogana, nego da štoviše opsjedaju njihove gradove, a osnovicu su za to u Pismu našli u Pnz 20,20 (BT Shabbat 19a9). 


\section{Hillēl i Isus kao hăanāmîm ili učitelji mudrosti i vjerozakona}

Mnogo je poveznica između najranijih kršćana i farizeja, a još više između "Isusove škole" i Hillēlove škole.

Ḥillēl i Isus uzdizali su etičku poruku čovjekoljublja kao središnju poruku židovstva, i promicali miroljubivo židovstvo - otvoreno prema poganima i suradljivo s rimskom vlašću. Hillēl je po zanimanju bio drvosječa, ${ }^{8}$ a Isus drvodjelja ili tesar (ó $\tau \dot{\varepsilon} \kappa \tau \omega v$, Mk 6,3), i svaki je bio učitelj s velikim mnoštvom učenika, naime njih »osamdeset « odnosno (barem) »sedamdeset [i dva]《 (BT Sukkah 28a: שִׁמוֹנִים

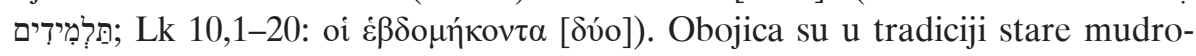
sne književnosti (Izr) poučavali u kratkim izrekama, ali poučavali su i po kasnije razvijenim metodama "istraživanja" i izlaganja dubljega smisla raznih mjesta iz

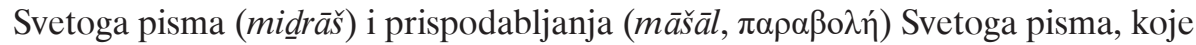
također Pismo izlaže dalje od doslovnoga značenja (BT Soferim 16,9; Mk 4,2). Obojica su dakle stajali u tradiciji ili pokretu nesvećeničkih iliti laičkih učitelja vjerozakona koji su se za zaradu u pravilu bavili nekim obrtom umjesto da zarađuju poučavanjem, a koje kasniji rabinski izvori u pravilu nazivaju hăk̆k̄mîm, što znači „mudraci, zanatski stručnjaci, (postbibl.) učenjaci“ (Werber, 1982, 19-20; Klein, 1987, 216). Istoj kulturnoj pojavi karakterističnoj za doba Drugoga hrama pripadaju i neki drugi slavni uzori židovstva i kršćanstva, primjerice Šammây kao graditelj (B. Talmud, Shabbat, 31a) i farizej Savao preobraćen na kršćanstvo pod imenom Pavao kao šatoraš (Dj 18,3). Takve su "učitelje mudrosti" (oi $\delta 1 \delta \alpha ́ \sigma \kappa \alpha \lambda o$ o бoфías) posjećivali i saduceji, samo što oni, za razliku od farizeja (i kršćana), nisu prihvaćali - samo na osnovi poštovanja spram učiteljâ iz prethodnih naraštaja — preinačavanje ikojih pisanih vjerozakonskih naloga (Tore), kao ni noviju nauku o uskrsnuću mrtvih, nego su dapače vrlinom smatrali prepirati se ( $\dot{\mu} \mu \varphi \imath$ ¡ s takvim učiteljima (Josip Flavij, 1890, 142-143; Antiquitates Judaicae 18.12-17; usp. saducejsko propitivanje Isusa u Mk 12,18-27).

Naziv hăk̆āmîm (slično kao u staroj Helladi oi ooøoí) mogao je u biblijsko doba označavati stručnjake čija je "mudrost" (hookmâ) ili, bolje, znanje zanatsko, dakle obrt bilo koje vrste (məlâk $\underline{a})$, čemu zorno svjedoče upute za gradnju Šatora sastanka sa svim namještajem u Knjizi izlaska (Izl 31,1-11). Mogao je također

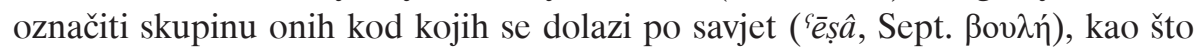
se kod svećenika dolazi čuti vjerozakon (Tôrâ, vó $\mu$ s), a kod proroka besjede

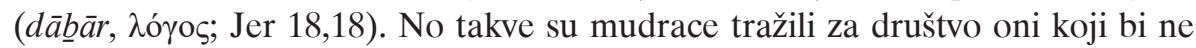
samo rado poslušali savjet, nego i primali njihovu pouku (ili "stegu, ćudoređe", hebr. mûsār) te sami postali mud(a)r(c)ima (Izr 13,20 i 19,20), čime bi "upute mudraca" (hebr. tôrat hāk $\underline{a} \bar{m}$ ) postale "izvorom života", koji izbavlja čovjeka od "zamkâ smrti" (Izr 13,14). Izgleda da su se oba ta značenja — "zanatski stručnjak" i "savjetodavac životne (ćudoredne) i spasonosne (soteriološke) mudrosti”

8 Tako doduše o njem svjedoče nešto mlađi dokumenti u tradiciji, a stariji neodređenije kažu da je bio najamni radnik (Buxbaum, 2004, 303-304, 305-306). 
— slila u opis naraštaja koji rabinska tradicija zove ḩăknāmîm i po kojem ta riječ počinje značiti i "učenjaci (pisanoga i usmenoga vjerozakona)".

No u njihovo su ih doba drugi oslovljavali kao "učitelje" (hebr. rabbî, grč. $\delta 1 \delta \alpha ́ \sigma \kappa \alpha \lambda o \varsigma$, Mt 23,1-8), a oni su kao učena klasa mogli biti prepoznatljivi pa i sebe zvati sôprîm, "pisari” (grč. $\gamma \rho \alpha \mu \mu \alpha \tau \varepsilon i \check{c})$ po uzoru na Ezru, "pisara svećenika"

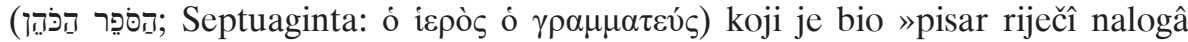

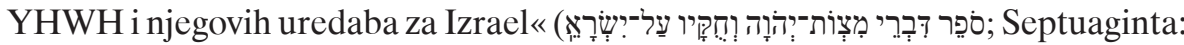

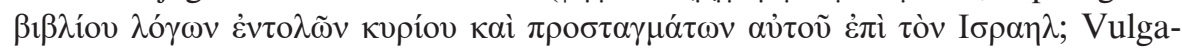
ta: sacerdos scriba eruditus in sermonibus et praeceptis Domini et caerimoniis eius in Israhel, Ezr 7,11, vlastiti prijevod Lj. F. J.). Učene "pisare" imala je dakako sljedba farizeja, ali zacijelo i druge sljedbe kao saduceji i (judeo)kršćani (usp. Mk 2,16; Dj 23,9; Mt 23,34; Twelftree, 2000, 1087). Stariji dijelovi Novoga zavjeta kao dokumenti 1 . stoljeća nedvojbeno potvrđuju takvu uporabu naziva "pisari" ( $\gamma \rho \alpha \mu \mu \alpha \tau \varepsilon \tilde{\varsigma})$, ali ponegdje to potvrđuju i rabinski izvori. U Babilonskome Talmudu (BT Sotah 15a13) nalazi se, primjerice, baraita $^{9}$ koja svjedoči da se je Gam(a)li’ēl Starješina, ${ }^{10}$ unuk Hiillēlov i nāsî́ nakon Šammâya (otprilike

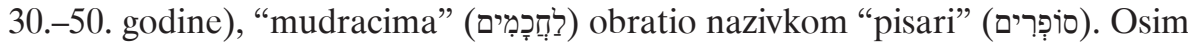
toga, stariji Talmud, naime Jeruzalemski Talmud, svjedoči da su se »pravorijeci Ḥillēlove škole« (dibrêe Bêt Hillēl) podvodili pod "pravorijeke pisara « (dibrêe sôprîm) (JT Berakhot 1,4). Budući da su rabini prikazivali svoju (usmenu) predaju kao da potječe sve od Mojsija, i da dakle svakako uključuje i niz učenih pisara u nastavku na Ezru sve do Šim ${ }^{\varsigma}$ ona Pravednika ${ }^{11}$ (Mishnah, Pirkei Avot, 1,1-2; Bowker, 1973, 18), ne čudi da je i naziv “pisari” bio u optjecaju i nakon Šim ${ }^{\varsigma}$ ôna Pravednika, iako su kasniji rabini učitelje nakon Šim'ôna Pravednika radije zvali

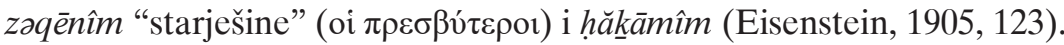

Doista, naziv hăk̆āmîm veoma se rijetko izravno javlja u evanđeljima. Samo na jednom mjestu u izvoru Q iz kojega crpe Matej $(11,25)$ i Luka $(10,21)$ Isus ih spominje jer slavi Boga zato što je spasonosni put »sakrio od mudrih i umnih «

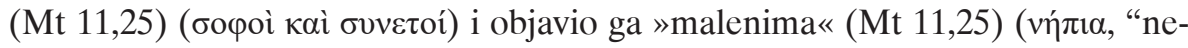
jačad”, tj. početnicima u Pismu, vjerozakonu i spasonosnoj nauci; usp. Hebr. 5,12-6,3). Takvo čitanje potvrđuje Pavao kada se za identifikaciju onih koji će propasti na Sudnjem danu poziva na mjesto $\mathrm{u}$ Pismu na koje Isus gore aludira (Iz 29,14): 12 »Upropastit ću mudrost mudrih i odbaciti umnost umnih « (1 Kor

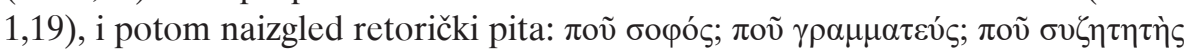

9 Baraita ili berajta je zbirka tanaitskih učenja (halaha i hagada) koja nisu uvrštena u Mišnu Jəhûde Kneza (engl. transkripcija: Yehudah ha-Nasi / the Prince; hrvatska: Jehuda Hanasi po Da-Don, 2009, 514) pa se stoga zove "izvanjska" (aram. bāraytâ). Te su usmene predaje već Jəhûdini učenici uvelike uredili i zapisali u zasebnim zbirkama, od kojih je glavna Tosefta, a često se navode i u Talmudu (Da-Don, 2009, 515; Werber, 1982, 62).

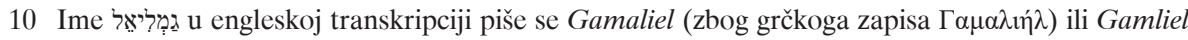
(zbog hebrejskoga zapisa), a u hrvatskoj Gamliel (Da-Don, 2009, 494).

11 Ime שִמְעוֹן הַצִדיק u engleskoj transkripciji piše se Simeon (the Just), a u hrvatskoj Šimon Pravedni (Da-Don, 2009, 474).

12 U Mk 7,6-7 Isus redak ispred u Izaiji (Iz 29,13) izravno primjenjuje na farizeje i neke pisare iz Jeruzalema. 


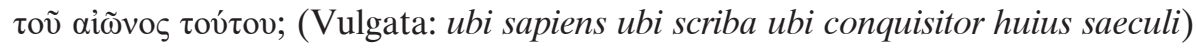
»Gdje [je] mudrac? Gdje pisar? Gdje (su)istraživač ovoga svijeta? « (1 Kor 1,20, vlastiti prijevod Lj. F. J.). Ta su retorička pitanja zapravo parafraze drugih Izaiji-

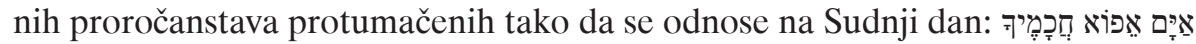

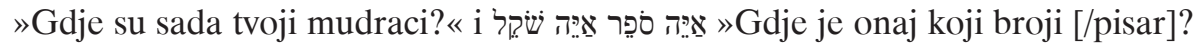
Gdje je onaj koji mjeri? «(Iz 19,12 i Iz 33,18, vlastiti prijevod Lj. F. J.).

Pisac Matejeva evanđelja svakako je i po naobrazbi i po slušateljima na koje smjera bio sličniji (i zato suprotstavljeniji) farizejskim učenim pisarima nego ostali evanđelisti. Zato Isus u njegovu evanđelju podrobnije razlaže stara proročanstva u novim prispodobama i zaključno o sebi i svojim učenicima kaže: »Zato

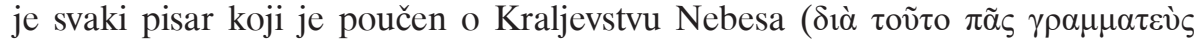

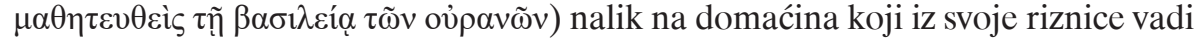
staro i novo« (Mt 13,52, vlastiti prijevod Lj. F. J.).

S time se slaže to što po Matejevu evanđelju Isus protiv farizejâ i pisarâ kao svoje učenike šalje »proroke i mudrace i pisare « (Mt 23,34, vlastiti prijevod Lj. F.

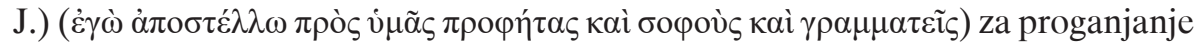
i krv kojih će se farizejima i pisarima najstrože suditi na skorašnjem Božjem sudu (Mt 23,33-36). Usporedimo li to s paralelnim mjestom u Luke gdje Isus kaže da »Zbog toga i kaza Mudrost Božja: 'Poslat ću k njima proroke i apostole' « (Lk 11,49), možemo zaključiti da su po Mateju Isusovi apostoli "mudraci i pisari" (hăǩāmîm i sôprîm), kao što je to i on sam, i da su njegovi slušatelji judeokršćani koji još uzorno obdržavaju Mojsijev vjerozakon (Mt 5,17-20).

U Talmudu je sačuvan samo trag toga da je iz takve škole mogao poteći Isusov učenik po kojem bi Isus bio hă $\underline{k} \bar{a} m$ koji dijeli vjerozakonske pravorijeke, a on sam tannâ „ponavljač, tanait“ (aram.) Isusova tumačenja vjerozakona, ali svrha je dotične pripovijesti iz Gemare samo da se naruga judeokršćanstvu kao "herezi" (מִינוּת) (BT Avoda Zarah, 16b15-17a4).

Sudeći po Matejevu evanđelju, Isus ni pred narodnim mnoštvom i učenicima nije osporavao autoritet učenim pisarima i farizejima: »Na Mojsijevu stolicu zasjedoše pisari [oi $\gamma \rho \alpha \mu \mu \alpha \tau \varepsilon i \tilde{c}$ ] i farizeji. Činite dakle i obdržavajte sve što vam kažu« (Mt 23,2-3, vlastiti prijevod Lj. F. J.).

Takav stav poštivanja vjerozakonskih naloga one farizejske škole koja je većinska, pa bila ona i Šammâyeva, imala je Hiillēlova škola kad je god bila u manjini (Falk, 1985, 12). Osim po pitanju dopustiva razloga za otpuštanje žene, kod kojega je Hiillēl bio veoma popustljiv, Isus se je s Ḥillēlovom školom, za razliku od Šammâyeve škole, možda načelno i mogao slagati u pristupu vjerskopravnim pitanjima i dobrim se dijelom preklapati u etičkim načelima i njihovu soteriološkome obzoru, kako će se u nastavku rada, zbog ograničenosti prostora, samo manjim dijelom moći pokazati. 


\section{Veze Hillēlovih potomaka s prvim kršćanima i Hillēlovih učenika s rabinskim židovstvom}

Po Ḥillēlovoj smrti, u službi ga je možda naslijedio njegov sin Šim ôn ben Ḥillēl, koji je možda umro iste godine, o kojem se malo zna, a neki ga kršćani izjednačuju sa starcem Šimunom koji je u Jeruzalemskome hramu blagoslovio dijete Isusa (Lk 2,25-35; Cutler, 1966). Ta se sporna identifikacija vjerojatno zasniva na miroljubivu i tolerantnu stavu Šimº̂nova sina Gam(a)liēla Starješine

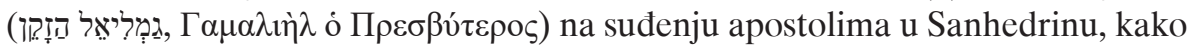
barem svjedoče Djela apostolska (Dj 5,34-39), gdje se Gamali’ēl uvodi kao $\tau 1 \varsigma$

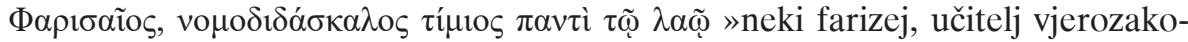
na cijenjen u svem narodu « (Dj 5,34, vlastiti prijevod Lj. F. J.). Ḥillēlova škola vjerojatno je imala dosta utjecaja na kršćanstvo i zato što je apostol Pavao, iako rođen u Tarzu, odrastao u Jeruzalemu, gdje je »do nogu Gamalielovih« (Dj 22,3)

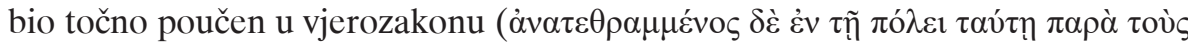

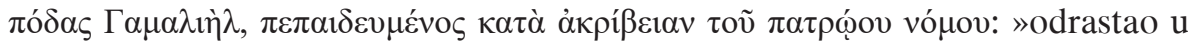
ovome gradu, točno obrazovan u vjerozakonu otaca [sjedeći] do Gamaliēlovih nogu « (Dj 22,3, vlastiti prijevod Lj. F. J.). Pretpostavlja se da je Gamali’ēl Starješina bio nāsî́ nakon Šammâya, dakle oko 30.-50. godine. Gamali’ēlov sin, dakle Hiillēlov praunuk, naslijedio je potom službu nāśî i vršio ju sve do svoje mučeničke smrti u Židovsko-rimskom ratu (70. godine), a na službi ga je naslijedio Hillēlov učenik Jôhānān ben Zakkây ${ }^{13}$ (do oko 80 . godine), otac rabinskoga židovstva po razrušenju Hrama u Jeruzalemu, čija je škola bitno utjecala na konačnu prevlast Hillēlove škole nad Šammâyevom.

\section{Vezivanje religije uz moral i uključivanje čovjekoljublja u štovanje Boga}

U slavnoj anegdoti o nekome poganinu koji je prvo Šammâya a potom Hiillēla zatražio da ga preobrati na židovstvo pod uvjetom da ga pouči cijelomu vjerozakonu dok stoji na jednoj nozi, Hillēlov je ovako sabrao cio vjerozakon: (BT Shabbat 31a6): “Što je tebi mrsko, ne čini svojemu drugu (חָרָר). Ta [micva] jest sva Tora u njezinoj potpunosti. Ostalo je njezino tumačenje [פירוּר]]. Idi, uči [dosl. dovršii]!"

Hiillēlovo pak čovjekoljublje (i miroljubivost) ocrtava prva i glavna njegova

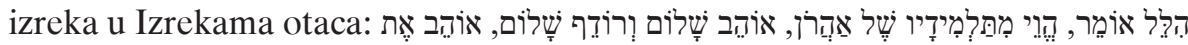

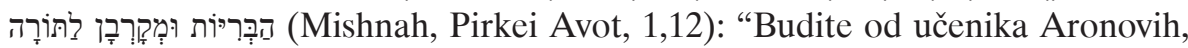
ljubeći mir i šireći mir, ljubeći [ljude kao Božje] stvorove i privodeći ih $\mathrm{k}$ vjerozakonu."

Ḥillēl je bio hạsî́, tj. posebno pobožan Židov čija pobožnost dolazi iz njegove ljubavi, i to ne samo prema Bogu, nego iz ljubavi prema Bogu koja uključuje ljubav prema bližnjemu čovjeku (Buxbaum, 2000, 161).

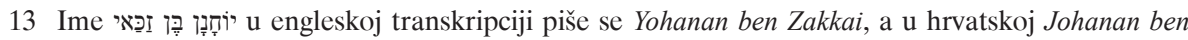
Zakaj (Da-Don, 2009, 512). 
S time se je već u 19. stoljeću znala usporediti, a treba se i danas usporediti, formulacija etičkoga Zlatnoga pravila i vrhovne zapovijedi (micve) kako ih Isus daje po evanđeljima:

1. Zlatno pravilo (u Mt 7,12 i Lk 6,31) - Pri kraju čuvene "besjede na gori"

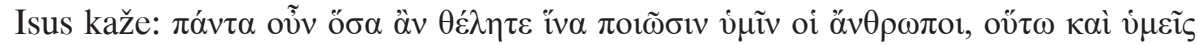

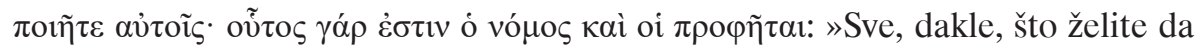
ljudi vama čine, činite i vi njima. To je, doista, Zakon i Proroci« (Mt 7,12).

2. Vrhovna zapovijed: »Ljubi svoga bližnjega kao sebe samoga« (Mt 22,39; Mk 12,31; usp. Lk 10,27).

U Jeruzalemskome hramu odvio se je čuveni razgovor između Isusa i nekoga neimenovanoga pisara o najvećoj vjerozakonskoj zapovijedi koji se dobro može usporediti sa zahtjevom poganina Hiillēlu. Razgovor prikazuju sva tri sinoptička evanđelja, no prikaz u Markovu evanđelju ne samo da je najstariji nego se čini i najautentičnijim, utoliko što u njem pripovjedač ne uvodi susret zakonoznanca i Isusa kao još jednu kušnju farizejâ Isusu (Mt) pa ni kao kušnju zakonoznanca bliskoga svećenicima (saducejima?) Isusu (Lk), nego kao razgovor u kojem oba sugovornika utvrđuju da se slažu u tome koje su dvije zapovijedi (micve) od svih izvedivih iz Tore glavne. Budući da Isusov sugovornik uzdiže ljubav prema Bogu i bližnjemu iznad obrednih žrtava, a to znači iznad saducejskoga hramskoga bogoslužja, lako je moguće da je pripadao Ḥillēlovoj školi. ${ }^{14}$ Druga dva evanđelja pomažu u takvoj identifikaciji utoliko što pisara ( $\gamma \rho \alpha \mu \mu \alpha \tau \varepsilon v \varsigma)$ tumače kao zakonoznanca (vouıós), ${ }^{15}$ a Matejevo ga evanđelje povrh toga svrstava u farizejsku sljedbu. Ako se je radilo o hillēlovcu, ne čudi da su se Isus i on po tome pitanju složili u oprjeci spram saduceja (Mk), a ako je riječ o šammâyevcu ili saducejskom zakonoznancu, moguće je da je on Isusa pitanjem iskušavao (Mt i Lk).

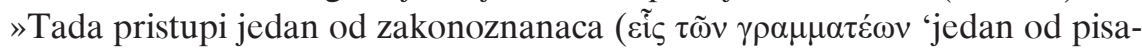
ra') koji je slušao njihovu raspravu [tj. između saducejā i Isusa]. Vidjevši da im

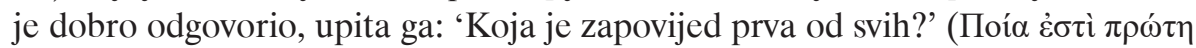

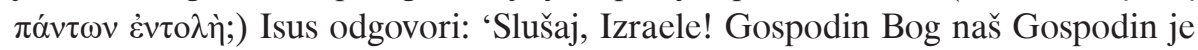
jedini. Zato ljubi Gospodina Boga svojega iz svega srca svojega, i iz sve duše svo-

14 Usp. kako se hillēlovski BT Avot d'Rabbi Natan 4,5 jednako kao Mk 12,33, Mt 9,13 i 12,7 poziva na Hoš 6,6 »milosrđe mi je milo, ne žrtva«, pri čem na obama mjestima u Mateju Isus za prigovor farizejima vjerojatno iznosi njihovo vlastito načelo, ali u njima neočekivanoj primjeni.

15 Izvorni naziv za "pisara” (grč. $\gamma \rho \alpha \mu \mu \alpha \tau \varepsilon u ́ s, ~ h e b r . ~ s o \bar{p} e r)$ evoluirao je s vremenom iz "sudskoga pisara" u "sudskoga tumača vjerozakona", a otprilike u Isusovo doba farizeji su počeli zamjenjivati (sudske) pisare kao tumači vjerozakona u svakodnevici, ali i na sudovima, usp. Bowker, 1969, 5556; Bowker, 1973, 22-23. Epiphanij Salaminski u svojem hereziološkome djelu Panarion opisuje "pisare" ( $\gamma \rho \alpha \mu \mu \alpha \tau i \tilde{\varsigma})$ kao zasebnu židovsku sljedbu koja je stara koliko i saducejska ili nešto mla-

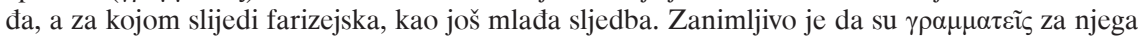

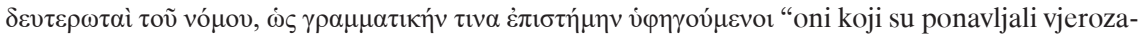
kon poučavajući [ga] kao neko gramatičko znanje" (Epiphanij, 1858, 244; Adversus Haereses, cap. $15,1,1)$. Tannā’im su se doslovno prevodili na grčki kao $\delta \varepsilon v \tau \varepsilon \rho \omega \tau \alpha i ́$ "učitelji ponavljanjem", a

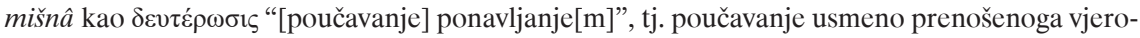

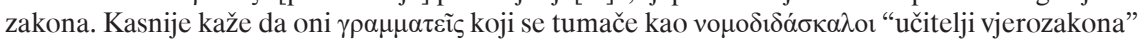
imaju stavove dijelom kao farizeji jer "pisarima" pripadaju i voнıкоí "zakonoznanci" (Epiphanij, 1858, 248; Adversus Haereses, cap. 16, 1, 1). 
je, i iz svega razuma svoga, i iz sve snage svoje! - to je prva zapovijed.' (پ̋אove,

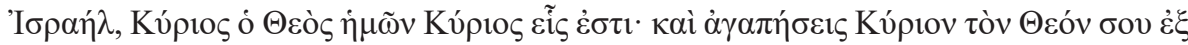

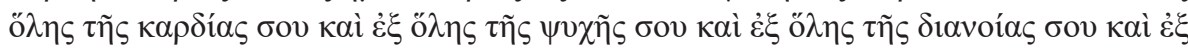

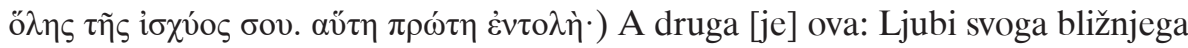

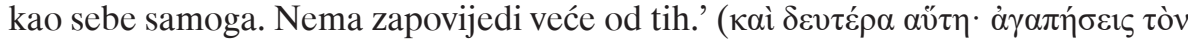

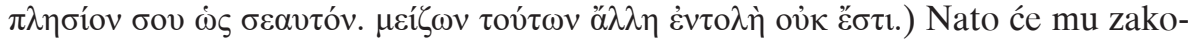
noznanac (ó $\gamma \rho \alpha \mu \mu \alpha \tau \varepsilon v ́ \varsigma)$ : 'Dobro, učitelju! (K $\alpha \lambda \tilde{\omega} \varsigma, \delta 1 \delta \alpha ́ \sigma \kappa \alpha \lambda \varepsilon)$ Po istini si kazao: On je jedini, nema drugoga osim njega. Njega ljubiti iz svega srca, iz svega uma, iz sve duše i iz sve snage i ljubiti bližnjega kao sebe samoga — više je nego sve pa-

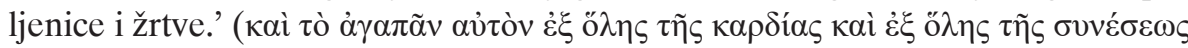

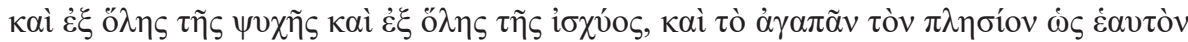

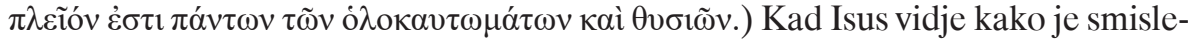
no odgovorio, reče mu: 'Nisi daleko od Kraljevstva Božjega!' I nitko se više nije usuđivao pitati ga.“ (Mk 12,28-34, vlastiti prijevod Lj. F. J.)

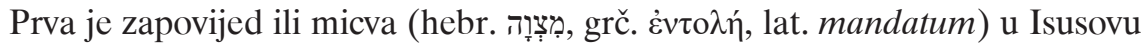
odgovoru ovdje u cjelini vjeran navod iz Ponovljenoga zakonika (Pnz 6,4-5, što je početni dio molitve Šəma Yiśra'el, koju Židovi svakodnevno dva puta mole),

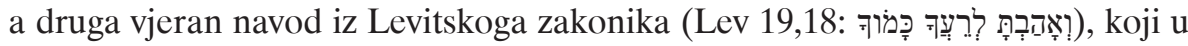

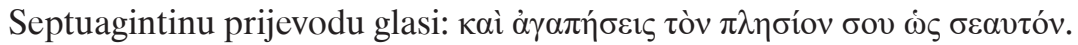

Da su te dvije zapovijedi te etičko Zlatno pravilo smatrane središnjima za kršćanstvo, vidi se i iz spisa Didaché, ili Gospodinova nauka za narode po dvana-

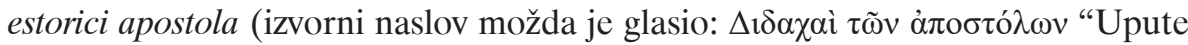
apostolske"). To je jedan od najstarijih (judeo)kršćanskih spisa, nastao između 80. i 100. godine, koji se još poziva na (neodređeno) "evanđelje Gospodinovo", ${ }^{16}$ a služi kao katehetski sažetak kršćanske nauke i kao upute za mlade crkve, još nehijerarhizirane i dobrim dijelom judeokršćanske, diljem Syrije, možda i širega Bliskoga istoka i Egipta. ${ }^{17}$ Spis kao svoje prve dvije upute navodi upravo gornje dvije zapovijedi (Pnz 6,5 i Lev 19,18), na koje se — kao objašnjenje (!) - nadovezuje Zlatno pravilo u negativnoj inačici, dakle u formulaciji koja je

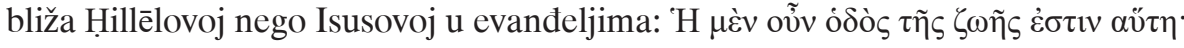

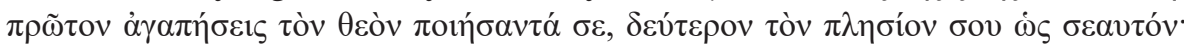

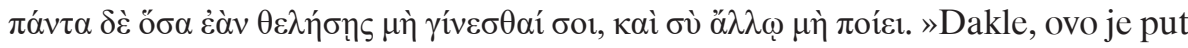
života: ponajprije ljubi Boga koji te je stvorio, zatim bližnjega svoga kao samoga sebe; doista ništa što ne želiš da tebi bude ni ti ne čini drugomu « (Bodrožić, 2010, 16; Didaché, cap. 1, 2).

Nakon Isusove smrti, slavan učitelj u Hillēlovu nizu i mučenik pri gušenju ustanka Bar Kôkbe (135. godine) ${ }^{\complement}$ Ăqīi $\underline{b} a ̂$ ben Yōsēp ${ }^{18}$ istu je zapovijed (micvu Lev 19,18) koju je Isus proglasio drugom glavnom zapovijedi sâm proglasio glavnim načelom Tore, i njime obuhvatio, kao nekoć Hịllēl, cijeli židovski vjerozakon:

16 Iako ima sličnosti napose s Matejevim, spomenuto "evanđelje" mogu biti i usmeno prenošene "Izr(j)eke Gospodnje".

17 Takva se ocjena spisa nalazi u predgovoru njegovu hrvatskomu prijevodu u: Bodrožić, 2010.

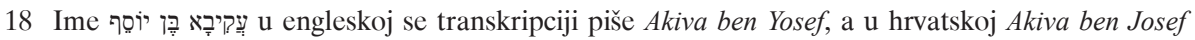
(Da-Don, 2009, 513). 


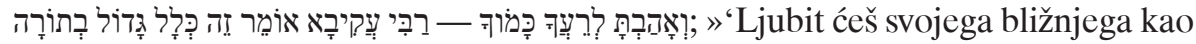
sebe samoga' — rabin Akiva kaže: to je veliko sveobuhvatno načelo u vjerozakonu [Tori] (Midrash, Sifra, Kedoshim, 4).

Dakako, te podudarnosti ne znače da je Isus morao uzeti Zlatno pravilo izravno od Hillēla i njegove škole, nego da su obojica, kao i njihovi sljedbenici, mogli crpsti iz zajedničke židovske usmene predaje. To potvrđuje u prvoj polovici 1. stoljeća Philōn Alexandrijski, koji navodi Zlatno pravilo kao dio nepisanoga vjerozakona, i to stavlja na prvo mjesto među inače neporedanim nepisanim pra-

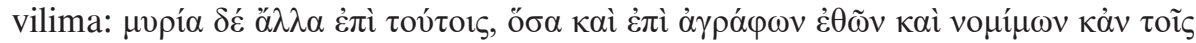
vó drugih stvari [pripada] nepisanim običajima i vjerozakonskim propisima ako i nisu već [sadržane] u samim zakonima. Što tko mrzi trpjeti, neka sam ne čini ${ }^{19}{ }$ « (Philōn Alexandrijski, 1985, 426; Hypothetica 7,6).

Još stariji zapis istoga etičkoga pravila iskazanoga kao Božja zapovijed ( $\dot{v} v \tau$ ¿ń, micva) nalazi se u knjizi Tobija, nastaloj vjerojatno na prijelazu 3. u 2. stoljeće pr. Khr., a cjelovito sačuvanoj jedino u grčkom prijevodu (u novije su doba pronađeni i hebrejski i aramejski ulomci knjige, od kojih je aramejski možda čak i izvornik). U knjizi se naime u 4. poglavlju nabrajaju opomene koje otac Tobit daje Tobiji pred sinov odlazak na put, a doimaju se da bi uvelike mogle

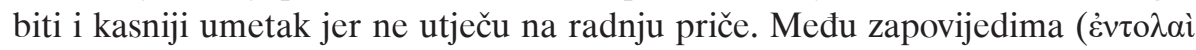

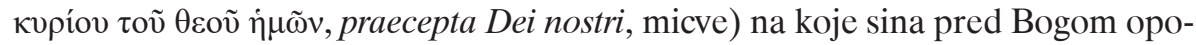

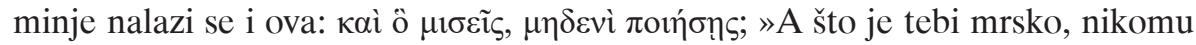
[drugom] ne čini.« (Tob 4,15, vlastiti prijevod Lj. F. J.).

\section{Dva primjera etičkih usporednica između Isusove i Hillēlove škole}

\subsection{Vrijednost poniznosti}

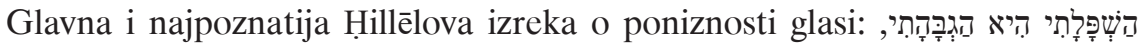

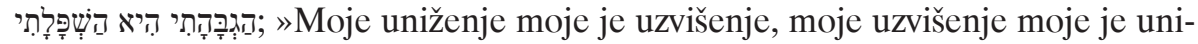
ženje« (Vayikra Rabbah, cap. 1, 5).

Vrijednost poniznosti toliko je bila raširena i cijenjena u Ḥillēlovoj školi da je rabinska tradicija tumačila njezinu konačnu prevlast nad Šammâyevom školom i njezinu potvrdu

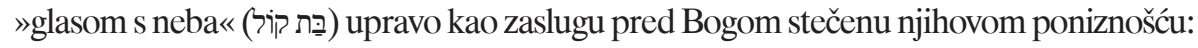

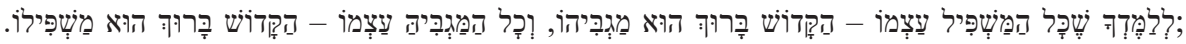
»[To se je zbilo tako] da te pouči da će svakoga tko unizuje samoga sebe Presveti [tj. Bog], blagoslovljen bio, uzvisiti, a da će svakoga tko uzvisuje samoga sebe Presveti, blagoslovljen bio, uniziti« (BT Eruvin 13b13).

U evanđeljima na više mjesta i u raznim primjenama nalazimo podudarnu

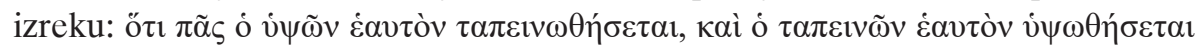
(Vulgata: quia omnis qui se exaltat humiliabitur et qui se humiliat exaltabitur); »jer

$19 \mathrm{Tj}$. što tko mrzi da mu drugi čini, neka ni on sam ne čini drugomu. 
— svaki koji se uzvisuje, bit će ponižen, a koji se ponizuje, bit će uzvišen « (Lk $14,11) \cdot{ }^{20}$

Istu poruku na još eksplicitniji način daje najstarija katolička poslanica, poslanica prvoga jeruzalemskoga biskupa Jakova, »brata Isusova«: $\tau \alpha \pi \varepsilon \imath v \omega ́ \theta \eta \tau \varepsilon$

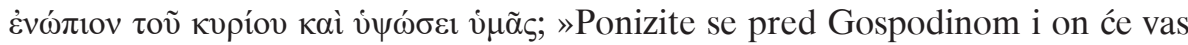
uzvisiti!«(Jak 4,10).

\subsection{Vrijednost milosrda}

Ḥillēl je bogatima uputio osobitu opomenu da se prisjete siromašnih članova

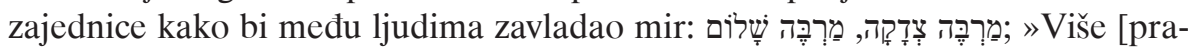
vednosti u liku] milostinje, više mira (Mishnah, Pirkei Avot 2,7; usp. Buxbaum, 2004, 238).

Isus je poticao svoje sljedbenike da pozajmljuju onima od kojih ne očekuju da im mogu vratiti, koji su možda nezahvalni ili zli, dakle da budu kao njihov Otac

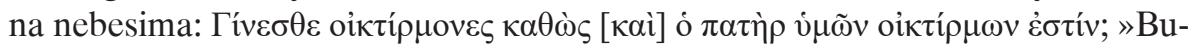
dite milosrdni kao što je Otac vaš milosrdan« (Lk 6,36).

Zbog tih dviju Ḥillēlovih vrlina židovski mudraci su ga ovim riječima komemorativno oplakali: »Jao [nama], milosrdni [hāsî̀ $\underline{\underline{a}}$ ], jao [nama], ponizni ['ānāw], učeniče Ezrin [- nema te više]!«(BT Sotah 48b7).

\section{Zaključak}

Kako sam u radu nastojao pokazati, vrijedna uporišta za židovsko-kršćanski međureligijski dijalog mogu se naći pomoću poredbene religiologije u povezanim tekstovima dviju velikih $\mathrm{i}$ isprepletenih tradicija abrahamskih religija jer nam oni otkrivaju zajedničke vrijednosti, pa i povijesne i dogmatske veze koje smo dijelom zaboravili i po kojima i vlastitu tradiciju možemo točnije i potpunije razumjeti. Zajedničke vrijednosti uvelike dolaze odatle što su Ḥillēl i Isus vezivali štovanje Boga i pobožni način života uz mirotvornu ljubav prema bližnjemu, etičko Zlatno pravilo i srodne etičke vrijednosti, od kojih su u ovome radu istaknute poniznost i milosrdnost. Gledajući iz takve poredbene perspektive, ovaj rad nastoji doprinesti tomu da se Isus razmatra kao židovski učitelj mudrosti i vjerozakona ( $h \bar{a} \bar{k} k \bar{a} m)$, i da se pritom njegov razgovor s nepoznatim „pisarom“ u Mk 12 tumači kao susret u dijalogu između Isusa i hillēlovca zabilježen u najstarijem kanonskome evanđelju. Taj susret tada se može prevrjednovati kao (pra)uzor židovsko-kršćanskomu dijalogu koji je neprimjetno ugrađen već u Novi zavjet.

20 Inačice i primjene u Lk 13,30, Mk 9,35-37, 10,42-45, Mt 18,1-5, 23,11-12, pa i u prvom blaženstvu Mt 5,3 gdje su »siromasi duhom« vjerojatno oni „ponizna duha“ ako grč. oi $\pi \tau \omega \chi o i ̀ ~ \tau \tilde{~}$

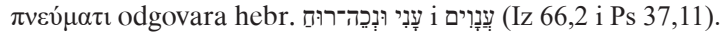




\section{Literatura}

Biblija. Sveto pismo Staroga i Novoga zavjeta. Prevoditelji: Silvije Grubišić (Petoknjižje), Filbert Grass (Psalmi), Nikola Miličević (Pjesma nad pjesmama), Antun Sović (ostali dijelovi Staroga zavjeta), Bonaventura Duda i Jerko Fućak (Novi zavjet). Imprimatur: Hrvatska biskupska konferencija, 10. listopada 2008. Zagreb: Kršćanska sadašnjost, 2015.

Bodrožić, Ivan (ur.) (2010). Apostolski oci II. Split: Verbum.

Bowker, John (1969). The Targums and Rabbinic Literature. Cambridge: CUP.

Bowker, John (1973). Jesus and the Pharisees. Cambridge: CUP.

Babilonski Talmud (BT) Avoda Zarah. U: Sefaria. URL: https://www.sefaria.org/Avodah_Zarah (15.12.2021.)

BT Avot D'Rabbi Natan. U: Sefaria. URL: https://www.sefaria.org/Avot_D'Rabbi_Natan (15.12.2021.)

BT Berakhot. U: Sefaria. URL: https://www.sefaria.org/Berakhot (15.12.2021.)

BT Chullin. U: Sefaria. URL: https://www.sefaria.org/Chullin (15.12.2021.)

BT Eruvin. U: Sefaria. URL: https://www.sefaria.org/Eruvin (15.12.2021.)

BT Gittin. U: Sefaria. URL: https://www.sefaria.org/Gittin (15.12.2021.)

BT Pesahim. U: Sefaria. URL: https://www.sefaria.org/Pesachim (15.12.2021.)

BT Sanhedrin. U: Sefaria. URL: https://www.sefaria.org/Sanhedrin (15.12.2021.)

BT Shabbat. U: Sefaria. URL: https://www.sefaria.org/Shabbat (15.12.2021.)

BT Soferim. U: Sefaria. URL: https://www.sefaria.org/Tractate_Soferim (15.12.2021.)

BT Sotah. U: Sefaria. URL: https://www.sefaria.org/Sotah (15.12.2021.)

BT Sukkah. U: Sefaria. URL: https://www.sefaria.org/Sukkah (15.12.2021.)

BT Yoma. U: Sefaria. URL: https://www.sefaria.org/Yoma (15.12.2021.)

Buxbaum, Yitzhak (2004). The Life and Teachings of Hillel. Lanham, Maryland: Roman \& Littlefield.

Cutler, Allan (1996). Does the Simeon of Luke 2 Refer to Simeon the Son of Hillel? Journal of Bible and Religion, 34(1), 29-35.

Da-Don, Kotel (2009). Židovstvo: Život, teologija i filozofija. Zagreb: Profil.

Didaché. U: Lake, Krisopp (prev.) (1965). The Apostolic Fathers in Two Volumes - I: I Clement; II Clement; Ignatius; Polycarp; Didache; Barnabas (str. 305-333). Loeb Classical Library. Cambridge: Harvard University Press.

Eisenstein, Judah David (1905). Scribes. U: Isidore Singer (ur.), The Jewish Encyclopedia: A Descriptive Record of the History, Religion, Literature, and Customs of the Jewish People from the Earliest Times to the Present Day: Volume XI: Samson — Talmid Hakam (str. 123-126). New York: Funk and Wagnalls Company.

Epiphanij. Panarion (Contra Haereses). U: J.-P. Migne (ur). (1858). Patrologia Cursus Completus: Series Graeca. Tomus XLI (str. 173-1200). Pariz: J.-P. Migne.

Falk, Harvey (1985). Jesus the Pharisee: A new look at the Jewishness of Jesus. New York: Paulist.

Grätz, Heinrich (21863). Geschichte der Juden von den ältesten Zeiten bis auf die Gegenwart: Dritter Band. Leipzig: Oskar Leiner.

Jastrow, Mark; Mendelsohn, S. (1902). Bet Hillel and Bet Shammai. U: Isidore Singer (ur.), The Jewish Encyclopedia: A Descriptive Record of the History, Religion, Literature, and Customs of the Jewish People from the Earliest Times to the Present Day: Volume III (str. 115-116). New York: Funk and Wagnalls Company. 
Josip Flavij (1890). Flavii Iosephi opera (ur. B. Niese, 1885-1895) - Vol. IV: Antiquitatum Judaicarum libri XVI-XX et Vita. Berlin: Weidmann.

Josip Flavij (1892). Flavii Iosephi opera (ur. B. Niese, 1885-1895) — Vol. III: Antiquitatum Judaicarum libri $X I-X V$. Berlin: Weidmann.

Jost, Isaac Markus (1857). Geschichte des Judenthums und seiner Secten: Erste Abtheilung. Leipzig: Dörffling und Franke.

Jeruzalemski Talmud (JT) Berakhot. U: Sefaria. URL: https://www.sefaria.org/Jerusalem_Talmud_Berakhot (15.12.2021.)

Klein, Ernest D. (1987). A Comprehensive Etymological Dictionary of the Hebrew Language for Readers of English. Jeruzalem: Carta.

Kuschel, Karl-Josef (2000). Spor oko Abrahama: Što Židove, kršćane i muslimane dijeli a što ih ujedinjuje. Sarajevo: Svjetlo riječi.

Lambdin, Thomas O. (1971). Introduction to Biblical Hebrew. New Jersey: Prentice-Hall.

Lujić, Božo (1996). Osnove hebrejskog jezika (scripta ad usum privatum). Zagreb.

Midrash, Sifra. U: Sefaria. URL: https://www.sefaria.org/Sifra (15.12.2021.)

Mishnah, Gittin. U: Sefaria. URL: https://www.sefaria.org/Mishnah_Gittin (15.12.2021.)

Mishnah, Pirkei Avot. U: Sefaria. URL: https://www.sefaria.org/Pirkei_Avot (15.12.2021.)

Mishnah, Sheviit. U: Sefaria. URL: https://www.sefaria.org/Mishnah_Sheviit (15.12.2021.)

Mishnah, Sukkah. U: Sefaria. URL: https://www.sefaria.org/Mishnah_Sukkah (15.12.2021.)

Mishnah, Yoma. U: Sefaria. URL: https://www.sefaria.org/Mishnah_Yoma (15. 12. 2021.)

Mishnah, Yevamot.U:Sefaria.URL:https://www.sefaria.org/Mishnah_Yevamot(15.12.2021.)

Philōn Alexandrijski (1985). Philo in Ten Volumes: IX. Cambridge: Harvard University Press.

Septuaginta (ur. Rahlfs/Hanhart). U: Deutsche Bibelgesellschaft. URL: https://www.academic-bible.com/en/online-bibles/septuagint-lxx/read-the-bible-text/ (15.12.2021.)

Stari zavjet na hebrejskome (izdanje Biblia Hebraica Stuttgartensia). U: Deutsche Bibelgesellschaft. URL: https://www.academic-bible.com/en/online-bibles/biblia-hebraicastuttgartensia-bhs/read-the-bible-text/ (15. 12. 2021.)

Twelftree, Graham H. (2000). Scribes. U: C. A. Evans i S. E. Porter (ur.), Dictionary of New Testament Background (str. 1086-1089). Illinois: InterVarsity Press.

Vayikra Rabbah. U: Sefaria. URL: https://www.sefaria.org/Vayikra_Rabbah (15.12.2021.)

Vulgata (ur. Weber/Gryson). U: Deutsche Bibelgesellschaft. URL: https://www.academicbible.com/en/online-bibles/biblia-sacra-vulgata/read-the-bible-text/ (15.12.2021.)

Werber, Eugen (1982). Povijest Talmuda. U: Eugen Werber (ur.), Talmud: Izbor i prijevod tekstova s hebrejskoga i aramejskoga, povijest Talmuda i bilješke napisao Eugen Werber (str. 9-140). Rijeka: Otokar Keršovani. 
On the Jewish-Christian Dialogue in the Encounter between Pharisaic and Jesus' Ethics

\section{Ljudevit Fran Ježić*}

\section{Summary}

The paper explores the ethics of the early (Jewish) Christians and Pharisees, two closely related Jewish sects at the beginning of the Common Era, through both $\mathrm{He}$ brew and classical philology as well as the comparative method within religious studies. It attempts to show that Jews and Christians can improve and complement their knowledge of their proper traditions and traditional values by means of a comparative study on the writings of the other's tradition. The paper enumerates and explains five important distinctions between the Pharisaic Schools of Hillel and Shammai. Furthermore, it reconsiders the Hakamic movement as a peculiar phenomenon of the Second Temple period of which Hillel and Jesus, both teachers of wisdom and Jewish Law, were in fact representatives. It compares the formulations of the Golden Rule by Hillel, Jesus and the Didaché and argues that both Hillel and Jesus derived the Rule from their common oral tradition of Law. Its presence in the Oral Law is affirmed by Philo of Alexandria and the Book of Tobit. Moreover, the discussion in Mark 12 on the greatest commandment is interpreted as a pleasant encounter in dialogue between a scribe of Hillel's School and Jesus. It is argued that this encounter illustrates how a fruitful Jewish-Christian dialogue can be based on the cognate heritage and values of Judaism and Christianity which are rooted in the Schools of Hillel and Jesus. This holds true especially for the way in which both Schools linked the pious way of life to high moral standards and love for one's fellowmen.

Keywords: Jewish-Christian dialogue; Hillel the Elder; School of Hillel; Pharisaic ethics; ethics of Jesus; Golden Rule; greatest commandment; humility; charity

* Ljudevit Fran Ježić, Ph.D., Assistant Professor, Faculty of Humanities and Social Sciences, University of Zagreb. Address: Ivana Lučića 3, 10000 Zagreb, Croatia. E-mail: ljfjezic@gmail.com 